\title{
ATRANKOS PROBLEMA, SVARBIAUSIOS REKOMENDACIJOS IR MODELINĖS CHARAKTERISTIKOS ATRENKANT JAUNUOSIUS BOKSININKUS İ PRADINIO RENGIMO GRUPES
}

\author{
Vidas Bružas, Vitalijus Subačius \\ Lietuvos kūno kultūros akademija, Kaunas, Lietuva
}

\begin{abstract}
Vidas Bružas. Biomedicinos mokslų daktaras. Lietuvos kūno kultūros akademijos Individualių sporto šakų katedros docentas. Moksinių tyrimų kryptis — sportininkų rengimo valdymas.
\end{abstract}

\section{SANTRAUKA}

Literatūros analizè ir mūsu praktinè patirtis rodo, kad bokso treneriai gauna mažai informacijos ir retai taiko moksliškai pagristus atrankos ir prognozès kriterijus, kurie leistu kur kas tiksliau ìvertinti vaiku gabumus ir galimybes.

Šiuo metu iš esmès neegzistuoja pradine atranka i bokso grupes. Pagrindinis treneriu ir sporto mokyklu uždavinys yra grupiu komplektavimas. Dél atrankos kriteriju nebuvimo ir ju netaikymo daug vaiku nustoja sportuoti jau pradinio rengimo grupése (Мелихова, 1990; Winfried, 2001), ir tai neigiamai veikia aukšto sportinio meistriškumo boksininku rengima (Белашев, 2000; Полиевский и др., 2002; Гаськов, Кузьмин, 2008).

Apžvalgos tikslas - analizuojant literatūra apžvelgti gabumu išaiškinimo ir atrankos problema, susisteminti ir pateikti svarbiausias rekomendacijas ir modelines charakteristikas, reikalingas jaunu perspektyviu boksininku atrankai i pradinio rengimo grupes.

Pagrindinès išvados: 1) gabumai yra genetiškai determinuoti ir pasireiškia tik konkrečioje sportineje veikloje, o už šios veiklos jie gali iš viso neegzistuoti; 2) boksininko sportinio meistriškumo lygis priklauso ne tk nuo fiziniu, funkciniu, bet ir nuo psichiniu ypatybiu lygio; 3) bokso treniruotes pradèti lankyti galima ne anksčiau kaip nиo 9-10 m.; 4) svarbiausias preliminarios atrankos tikslas — ivertinti trukdžiu lygì (trukdys — tai tokios ypatybès, kurios neleis vaikui siekti puikiu sportiniu rezultatu): lètas informacijos prièmimas ir apdorojimas, nepakankams dèmesio paskirstymas ir jo intensyvumas, prastas erdvès ir laiko vertinimo tikslumas; 5) pirminiu boksininku atrankos etapu bütina nustatyti ju vestibuline funkcija ir kaita, pasitikejjimq savimi, greituma, jejga, staigiaja jèga, ištverme, gebejima atlikti tiesius smügius ir gintis nио ju; 6) antruoju boksininku atrankos etapu reikia nustatyti sportininku greituma, jëga, staigiajajegga, ištverme, technikos veiksmu lygì ir kaita, nuotolio jutima specifinèmis salygomis, paprasta ir sudètinga reakcija, taip pat jie turi atsakyti 3 teorinius klausimus.

Raktažodžiai: boksas, gabumu ir atrankos problema, rekomendacijos, modelinès charakteristikos, pradinio rengimo grupès.

\section{IVADAS}

$\mathrm{P}$ astovus sportinių rezultatų augimas ir didejjanti sportininkų konkurencija pasaulyje kelia vis didesnius reikalavimus ne tik sportininkų parengtumui, bet ir racionalesnei sportininku atrankai. Tik gero fizinio, funkcinio ir psichologinio parengtumo sportininkai, turintys igimtu gabumų konkrečiai sporto šakai, gali išlaikyti didèjančią konkurenciją (Мелихова,

1990; Гаськов, Кузьмин, 2008). Nuo to, kaip sèkmingai bus sprendžiama atrankos problema, priklauso bokso plètra mūsų šalyje, pasiekimai olimpinèse žaidynèse ir kitose tarptautinèse varžybose. Talentingus vaikus surasti labai sunku, todèl jų paieška turi būti labai gerai organizuota ir moksliškai pagrįsta (Мелихова, 1990; Winfried, 2001). 
Problema. Literatūros analizè, praktinè patirtis rodo, kad bokso treneriai gauna mažai informacijos ir retai taiko moksliškai pagrịstus atrankos ir prognozès kriterijus, kurie leistu kur kas tiksliau ivertinti vaiku gabumus ir galimybes. Šiuo metu iš esmès neegzistuoja pradinė atranka ị bokso grupes, o pagrindinis trenerių ir sporto mokyklų uždavinys yra grupiu komplektavimas (Полиевский и др., 2002). Dèl atrankos kriterijų nebuvimo ir ju netaikymo daug vaikų nustoja sportuoti jau pradinio rengimo grupese (Мелихова, 1990; Winfried, 2001), ir tai neigiamai veikia aukšto sportinio meistriškumo boksininkų rengimą (Полиевский и др., 2002).

Naujumas. Jaunujų boksininkų atrankos problema mažai nagrinèta, pasigendama rekomendacijų, reikalingų jaunų perspektyvių boksininku atrankai i pradinio rengimo grupes.

Pagrindinis šios apžvalgos tikslas - analizuojant literatūrą apžvelgti gabumų ir atrankos problemą, susisteminti ir pateikti svarbiausias rekomendacijas ir modelines charakteristikas, reikalingas jaunų perspektyvių boksininkų atrankai i pradinio rengimo grupes.

Pagrindinis tyrimo metodas - loginè dedukcinè mokslinès ir metodinès tiriamosios medžiagos analizè.

\section{GABUMU IR ATRANKOS PROBLEMOS APTARTIS}

Gabumo sąvoką pirmasis savo darbuose pavartojo žymus senovės graikų filosofas Platonas (428-348 m. pr. Kr.). Savo veikale „Valstybė” (2000) jis iškélè minti apie igimtą žmoniu nelygybę. Jam taip pat priklauso ideja apie gabumu kitimą. Toliau mokymą apie gabumus pletojo jo mokinys Aristotelis (384-322 m. pr. Kr.), kuris gabumus apibūdino kaip vidines potencines kūno ypatybes, „,be kurių išoriškai determinuota veikla negali būti efektyvi". Kiekvienas iš jų (gabumas ar negabumas) vadinamas taip ne todèl, kad kažkas yra tokios būsenos, o dèl to, kad turi igimtu gabumų lengvai kažką daryti (Аристотелъ, 1975). Konfucijaus mokinys Siun-Czy (313-238 m. pr. Kr.) rašè: „Reikia gerbti išmintingus ir panaudoti gabius suteikiant kiekvienam pareigas ir rangą, priderančius jų talentui $<\ldots>$ Nors žmogui gamta yra suteikusi nuostabias ypatybes ir išminti, jis dar turi gauti gera mokytoją ir visur juo sekti" (Гужаловский, 1978).

Sportuojančiam organizmui fiziškai tobulèti, jo organizmo treniruotumui didinti didelę itaką turi
Žmogaus fizinès veiklos genetinis paveldèjimas (Белашев, 2000). Pagal kokybinius požymius genetini paveldejjimą galima skirstyti į tris grupes: igymių, gabumų, talento (Radžiukynas, 2005).

Igymiai - tai elementarūs igimti organizmo ypatumai (Radžiukynas, 2005). Pavyzdžiui, gebejjimas vaikščioti, bėgioti, ivveikti daug pastangu nereikalaujančius fizinius sunkumus ir kt.

Gabumai - i̇vairių asmenybės požymių (morfologinių, funkcinių, psichologinių ir kt.) poreiškis konkrečioje sportinejje veikloje, kurie lemia pastarosios kokybę (Волков, 1981). Kaip rašo K. K. Platonovas (Платонов, 1972), „gabumai ne tik pasireiškia konkrečioje sportinejje veikloje, o už šios veiklos jie gali iš viso neegzistuoti." Dauguma autoriu (Волков, 1981; Radžiukynas, 2005) pažymi, kad gabumai sporto sirtyje yra genetiškai determinuoti. Kadangi motorikos vystymassi kažkiek lemia genotipas, galima teigti, kad kiekvienas individas treniruodamasis gali pasiekti tam tikrą, jam būdinga ribą, kurios viršyti jau nebegalès (Шварц, 1978; Zutkis, 1981). Savaime suprantama, kai šiuolaikinis mokslas yra pasiekęs toki lygi, kad konkrečios ribos kiekvieno žmogaus vystymęsi kol kas neimanomos.

Talentas - labai dideli kurios nors srities gabumai. Jị sudaro morfologiniu, fiziologinių, fizinių, psichologinių ir kitų igymių visuma (Radžiukynas, 2005). Jie pasireiškia tam tikroje veikloje, kuri sudaro palankias sąlygas siekti aukštumu ateityje. Talentas ugdomas ankstyvose gyvenimo stadijose ir priklauso nuo auklèjimo, aplinkos (Michel, Novak, 1983; Мартынов, 2002). Sportinis talentas ir sportinè treniruote yra vienas nuo kito neatsiejami ir vienas kitą papildo. Talentas pasireiškia tik tikslingai ir veiksmingai treniruojantis (Thiess, 1989).

Tinkamumas — žmogaus atitikimas atskiros sporto šakos reikalavimams (Zutkis, 1981). Netinkamu konkrečiai veiklai žmogus pripažistamas ne tik tada, kai neturi reikiamu gabumų, bet ir tada, kai jam dèl kai kurių priežasčių ta veikla neprieinama. Pavyzdžiui, dèl mažo deguonies suvartojimo yra netinkamas ištvermès sporto šakoms.

Gabumų nustatymo ir įvertinimo sistema praktikoje vadinama atranka. Tai nevienkartinis sportininko testavimas, o daugiametis procesas nuo naujoko iki olimpiečio (Запорожанов, 1990). Atrankos kriterijai - tai specialiuju judejjimo ypatybiu kokybinès ir kiekybinès charakteristikos, kuriomis remiamasi atrenkant vaikus $\mathfrak{i}$ sportines grupes (Мелихова, 1990). Atranka gali 
būti: socialine, etinè, pedagoginè, techninė ir kt. (Зациорский, Булгаков, 1980; Winfried, 2001). Tikslaus atsakymo, kokius atrankos kriterijus, metodus ar testus reikia taikyti vykdant atranką, kurie garantuotuc boksininko čempiono ar boksininko talento atradimą, niekas neduos, galima tiktai numatyti prieigos būdus ir žinoti tai, ką reikia daryti norint atranką padaryti veiksmingesnę. Atrankos pagrindinis tikslas yra aukštos klasès sportininko modelio ar modeliniu charakteristikų sudarymas (Платонов, Запорожанов, 1991; Мартынов, 2002). Modelines boksininkų charakteristikos turi būti sudarytos iš tokių rodiklių, kurie parodo boksininko parengtumo lygi (fizini, technini, taktini ir psichologini) (Белашев, 2000). Neužtenka žinoti vien tiktai galutines olimpinio čempiono ar rekordininko modelines charakteristikas, bet reikia išmanyti ir tai, kaip sportinis idealas formuojasi, kokiomis modelinėmis charakteristikomis jis išsiskiria kiekvienu sportinio tobulejimo etapu. Reikia atsiminti, kad kiekvienas organizmas priklausomai nuo igimtų, aplinkos veiksnių ir treniruotès metodikos vystosi individualiai (Волков, 1981; Гаськов, Кузьмин, 2008). Ne paslaptis, kad daug labai gabių boksininkų ir kitų šakų sportininkų nepasiekè olimpinių aukštumų dèl nemokšiškos trenerio veiklos. Tokios veiklos poreiškio formos yra individualaus priejimo prie sportininko stoka, rezultatu forsavimas, treniruotès vyksmo monotonija, atsigavimo priemonių stoka ir pan. (Winfried, 2001).

Prognozavimas — tai mokslinis numatymas, kaip ateityje pletosis atskiros funkcijos, objektas ar sistema ir kokiomis aplinkybèmis įvyks plètotès pokyčiai (Zutkis, 1981). Tai pats svarbiausias klausimas, sprendžiamas atrankos metu. Jei atskirų funkcijų plètrą galima prognozuoti, atranka iš principo galima, jei ne - atranka neimanoma (Волков, 1981; Таймазов, Бакулев, 2005).

Boksininkų atrankos organizavimas, pagrindiniai reikalavimai, atrankos etapai, modelinès charakteristikos. Siūlomos tokios praktinès atrankos organizavimo formos (Zutkis, 1981; Худадов, Васильев, 2001, Мартынов, 2002):

- Epizodinis bendrojo lavinimo mokyklu vaikų agitavimas, kuri atlieka pats treneris, sporto mokyklos, klubo atstovai, ižymūs sportininkai.

- Trenerio ir fizinio lavinimo mokytojo tarpusavio kontaktai. Treneris konsultuojasi su mokytoju apie atskiru vaiku sportinius gebejjimus ir polinkius atitinkamai sporto šakai, stebi fizinio lavinimo pamokas ir atskiru mokinių elgesi jose, mokytojui padedant atlieka kontrolinius testus. Ši forma yra vertingesnè už epizodinę, kadangi treneriui padeda specialistai, gerai pažistantys savo mokinius, žinantys jų stipriąsias ir silpnąsias savybes, charakterio bruožus ir pan.

- Vykdyti preliminarų jaunujų moksleivių rengimą atskirose bendrojo lavinimo klasèse. Du kartus per savaitę fizinio lavinimo pamokose vaikai turi būti mokomi pagrindiniu bokso pratimų, atliekamas testavimas, stebimas vaikų gebejjimų tobulejjimas. Tai turètų trukti apie $1-2$ metus. Mokymo proceso pabaigoje treneriai atrenka gabesnius vaikus i specialiąsias klases, bokso mokyklas ar klubus, kur jiems sudaromos galimybės siekti sportinių aukštumų. Šios formos privalumai: geresnè atrankos kokybė (matome vaikų gebejjimų pažangą, ne tik pradinius rezultatus), mažesnis psichologinis stresas (jeigu tas vaikas yra netinkamas šiai sporto šakai, be to, yra pripratęs prie savo mokyklos salès). Pagrindinis šios formos trūkumas yra organizacinis (specialistu alga, bazių stoka, lèšų stoka). Dèl to ši atrankos forma negali būti taikoma masiškai, nors jos pranašumas prieš kitas akivaizdus.

Pagrindiniai boksininku atrankos reikalavimai (Кличко, 1999; Белашев, 2000):

- Atrankos procese turi būti naudojamos visos pagrindinès jos formos, remiamasi ivvairių testu ir mèginiu rezultatais.

- Atranka bus veiksminga, jei bus atsižvelgiama ne i vieno testo rezultatus, bet remdamiesi daugelio duomenimis kompleksiškai ịvertinsime sportinius gabumus.

- Reikia atsižvelgti i konkrečias sąlygas. Pavyzdžiui, gal vaikas parode blogesni rezultatą ne todèl, kad jis yra negabus, o dèl to, kad niekada nèra to pratimo daręs.

- Atranka turi būti dinamiška, t. y. vykti etapais, o ne taptu vienkartine akcija. Daugelis specialistų mano, kad atrankos procese perspektyvūs pasirodo ne tie vaikai, kuriu pradiniai rezultatai labai geri, o tie, kuriu pagrindiniu fizinių ypatybiu gerèjimo tempai dideli per pirmuosius $1,5-2$ metus.

- Būtinas individualus prièjimas prie kiekvieno vaiko, t. y. reikia atsižvelgti ị kompensuojamąsias vaiko savybes. Dažniausiai geri boksininkai yra aukšti, ilgomis rankomis ir plonomis kojomis, todèl treneriai nenoriai ima nedidelio ūgio apkūnius vaikus. Visgi prieš paskelbiant, kad tie vaikai yra netinkami boksui, reikètu patikrinti jų fizines, funkcines ir psichologines savybes. Gal jis turi puikią funkcinę sistemą, gerą koordinaciją, o gal 
jo atkaklumas ar valia yra išskirtinè. Pavyzdžiui, Vidas Bičiulaitis, kurio ūgio, greičio, galingumo ir net technikos rodikliai nèra labai geri, išsiskyrè dideliu funkciniu pajègumu ir kovingumu. Jis iškovojo trečią vietą 1995 m. Pasaulio bokso čempionate.

- Igūdžių lygis, kurių pagrindu lavèja motoriniai gabumai, pasireiškia tik konkrečioje veikloje.

- Atskirų individų sportiniai gabumai pasireiškia įvairiais amžiaus tarpsniais. Be to, vaikų antropometriniai rodikliai ir atskiros fizinès ypatybès vystosi ne vienu laiku ir skirtingu tempu (akceleracija, kritiniai laikotarpiai, individualus lytinis brendimas ir pan.).

- Sprendimą apie vaiko tinkamumą reikètų daryti tik kryptingo treniruotès vyksmo metu, kada vaikas yra mokomas pagrindinių bokso pratimu atlikimo technikos ir taktikos.

- Kuo daugiau vaiku treneris išbandys, tuo mažesnès jo klaidu galimybès. Kuo daugiau atrinksime gabių vaiku ir kuo mažiau negabiu, tuo veiksmingesnè bus atranka ir didesnè galimybė atrasti talentingu vaiku.

- Reikia visada atsiminti, kad šimtaprocentinis prognozavimas yra neimanomas.

Sportinė atranka - ilgametis procesas, kai treniruočiu metu yra tikslinamos žinios apie sportininku gabumus. Yra skiriami trys pagrindiniai atrankos etapai (Зациорский, Булгаков, 1980):

- Preliminari atranka. Jos metu nustatoma, ar tikslinga vaikui kultivuoti boksą. Šiuo etapu nebūtina vaikui kelti labai didelių reikalavimų. Jei vaikas yra sveikas, nori kultivuoti šią sporto šaką ir nèra trukdžių, reikia priimti ji sportuoti. Trukdys - tai tokios ypatybès, kurios neleis vaikui siekti puikių sportinių rezultatu.

- Tikslinamoji atranka. Šiuo etapu prognozuojama, ar sékmingas bus jaunojo sportininko treniruotės vyksmas. Pagrindiniai kriterijai: fiziniu ypatybiu gerèjimo tempai, gebejjimas pakelti didelius pratybų krūvius, sportinès technikos išmokimo laipsnis, psichologinès, valios ypatybès ir pan.

- Sportine ,, selekcija”. Pagrindinis šio etapo tikslas - iš gabiu boksininku būrio (iškovojusiu $1-3$ v. LČ) atrinkti talentingus, galinčius pasiekti geriausių sportinių rezultatų. Šiuo etapu atsižvelgiama i specialiojo fizinio parengtumo lygi, gebejjimą gana stabiliai startuoti varžybose, fiziologinius rodiklius, kovingumą, motyvacijos lygi ir kryptinguma. Vis dèlto didžiausias dèmesys šiuo etapu turi būti skiriamas psichologiniam sportininko parengtumui (Мелихова, 1990).
Boksas - sudètingos koordinacijos, greičio jègos, nestandartinè aciklinè dvikovos sporto šaka. Dvikovos metu, laikydamiesi bokso taisyklių, kovoja du sportininkai, stengdamiesi suduoti vienas kitam kuo daugiau tikslesnių ir stipresnių smūgių minkštomis pirštinėmis dengtais kumščiais ir praleisti kuo mažiau smūgių nuo varžovo naudojant leistinus gynybos veiksmus. Jau iš bokso apibrēžimo galima suprasti, kad boksininko meistriškumo lygi lemia ne kokia nors viena ypatybè, o visas ju kompleksas (koordinacija, greitumas, greičio ištvermè, galingumas, reakcija, psichologinès ypatybès, funkciné sistema ir pan. (Худадов, Васильев, 2001). Todèl boksininkų atranka yra labai sudètinga.

Aukštos kvalifikacijos boksininko modelinès charakteristikos yra šios (Волков, 1981; Гаськов, 1989; Филимонов, 2006; Гаськов, Кузьмин, 2008 ):

- Varžybinès veiklos rodikliai.

- Fizinio išsivystymo rodikliai (antropometriniai duomenys).

- Fizinių ypatybių išugdymo lygis.

- Techninio parengtumo lygis.

- Taktinio parengtumo lygis.

- Funkcinès būklès rodikliai.

- Psichologiniai ypatumai.

- Amžiaus modelinès charakteristikos.

Boksininko judejjimas, veiksmų intensyvumas, reagavimo pobūdis, taktinių veiksmų eiga priklauso ne tik nuo paties savęs, bet ir nuo varžovo veiklos ringe (Волков, 1981). Norédamas išsiaiškinti, kas turi didžiausią poveiki jaunuju boksininku igūdžiu formavimuisi ir sèkmingai veiklai, V. M. Volkovas (Волков, 1981) atliko specialiuju kontrolinių pratimų rezultatu ir greičio, koordinacijos, jègos, greičio jègos, ištvermès rodiklių rezultatų koreliacinę analizę. Pasirodo, sėkmingą jaunujų boksininkų veiklą daugiausia lemia informacijos prièmimo ir apdorojimo greitis sudètingomis sąlygomis (sudètinga reakcija), demesio paskirstymas ir jo intensyvumas, erdvès ir laiko vertinimo tikslumas, vestibulinis jautrumas, susijęs su įvairiomis galvos padètimis ir atsparumu smūgiams, pasitikejimas savimi, koordinacija, greitumas. V. M. Volkovas (Волков, 1981) teigia, kad boksininkai, kuriu greitumo ir koordinacijos lygis pradinio rengimo etapu buvo aukštesnis, išsaugojo ši pranašumą per visą sportini staža.

Kaip jau minejjome, atliekant preliminarią atranką nebūtina vaikui kelti labai didelius reikalavimus ir sureikšminti visų modelinių charakteristiku 
1 lentelè. Vaikų fizinių ir psichinių ypatybių lygio nustatymo testai ir jų rodiklių pokyčiai per pirmą atrankos etapą (12-14 m.)

\begin{tabular}{|c|c|c|c|c|c|c|c|}
\hline Pavardè, vardas & \multicolumn{4}{|c|}{ Preliminari atranka } & \multicolumn{3}{|c|}{$\begin{array}{c}\text { Atranka ị pirmų metų pradinio } \\
\text { rengimo grupes }\end{array}$} \\
\hline Rodikliai & $\begin{array}{l}\text { Pradi- } \\
\text { niai }\end{array}$ & $\begin{array}{c}\text { Po } \\
1 \text { mèn. }\end{array}$ & $\begin{array}{l}\text { Po } \\
3 \text { mèn. }\end{array}$ & $\begin{array}{l}\text { Po } \\
6 \text { mèn. }\end{array}$ & Po $1 \mathrm{~m}$. & Po $1,5 \mathrm{~m}$. & Po $2 \mathrm{~m}$. \\
\hline $\begin{array}{l}60 \text { m bėgimas, s } \\
\text { (Романов, Дегтерев, 1984) }\end{array}$ & & & & & $9,5-9,7$ & $9,4-9,6$ & $9,3-9,5$ \\
\hline $\begin{array}{l}\text { Teniso kamuoliuko metimas, m } \\
\text { (Задорожный, Хохлов, 2004) }\end{array}$ & & & & & $18-20$ & $21-23$ & $24-26$ \\
\hline $\begin{array}{l}\text { Atsispaudimai, kartai } \\
\text { (Романов, Дегтерев, 1984) }\end{array}$ & & & & & $10-12$ & $13-15$ & $16-18$ \\
\hline $\begin{array}{l}\text { Plaukimas, m } \\
\text { (Романов, Дегтерев, 1984) }\end{array}$ & & & & & $20-30$ & $45-55$ & $70-80$ \\
\hline $\begin{array}{l}\text { Prisitraukimai, kartai } \\
\text { (Гаськов, Кузьмин, 2008) }\end{array}$ & & & & & $2-4$ & $3-5$ & $4-6$ \\
\hline $\begin{array}{l}\text { Šuolis į toli issibègejus, cm } \\
\text { (Гаськов, Кузьмин, 2008) }\end{array}$ & & & & & $2,95-3,05$ & $3,05-3,15$ & $3,15-3,25$ \\
\hline $\begin{array}{l}\text { Mokèjimas judèti, atlikti tiesius smūgius } \\
\text { ir gintis nuo jų (vertinama } 10 \text { balų skale) } \\
\text { (Романов, Дегтерев, 1984) }\end{array}$ & & & & & $4-5$ & $5-6$ & $6-7$ \\
\hline $\begin{array}{l}\text { Pasitikejjimas savimi (J. Kiseliovo skale } \\
\text { „Termometras“) } \\
\text { (Марищук, Блудов, 1990) }\end{array}$ & $\begin{array}{l}\text { Ne mažiau } \\
\text { kaip } \\
5 \text { balai }\end{array}$ &,,---- &,,---- &,,------ &,,------ &,,------ &,,------ \\
\hline $\begin{array}{l}\text { Informacijos prièmimo ir perdirbimo } \\
\text { greitis } \\
\text { (Landolto lentelë) } \\
\text { (Худадов, Фролов, 1970) }\end{array}$ & $\begin{array}{l}\text { Ne mažiau } \\
\text { kaip } \\
1 \text { bitas per } \mathrm{s}\end{array}$ &,,---- &,,------ &,,------ & ---,,--- &,,------ & ---,,--- \\
\hline $\begin{array}{l}\text { Dėmesio paskirstymas ir intensyvumas } \\
\text { (Burdono-Anfimovo korekcinè lentelè) } \\
\text { (Худадов, Фролов, 1970) }\end{array}$ & $\begin{array}{l}\text { Ne mažiau } \\
\text { kaip } \\
2 \sigma\end{array}$ &,,---- & --,,---- &,,------ & ---,,--- & --,----- &,,------ \\
\hline $\begin{array}{l}\text { Nuotolio jutimas (Nikifirovo metodika) } \\
\text { (Худадов, Фролов, 1970) }\end{array}$ & $\begin{array}{l}\text { Paklaida } \\
\text { ne didesnè } \\
\text { kaip } 3,1 \pm \\
0,14 \mathrm{~cm}\end{array}$ &,,---- &,,------ & ---,,--- & ---,,--- & ----,,-- &,,------ \\
\hline $\begin{array}{l}\text { Vestibulinių ir somatinių reakcijų dydis } \\
\text { (vertinama } 4 \text { balų skale) (otolitinis } \\
\text { reakcijos mėginys Or5) } \\
\text { (Rušas, Bagočiūnas, 1999) }\end{array}$ & $\begin{array}{l}\text { Ne mažiau } \\
\text { kaip } \\
3 \text { balai }\end{array}$ &,,---- & ---,,--- & --,,---- & $\begin{array}{l}\text { Apie } \\
1 \text { balą }\end{array}$ & $\begin{array}{l}\text { Apie } \\
1 \text { balą }\end{array}$ & $\begin{array}{l}\text { Apie } \\
1 \text { balą }\end{array}$ \\
\hline
\end{tabular}

Pastaba. Parengta pagal: Худадов, Фролов, 1970; Романов, Дегтерев, 1984; Задорожный, Хохлов, 2004; Гаськов, Кузьмин, 2008 геkomendacijas.

rodiklius. Jei vaikas yra sveikas, nori lankyti šią sporto šaką ir nèra trukdžių (lètai priima ir apdoroja informaciją, nepakankamai ir neintensyviai paskirsto dèmesi, prastai ir netiksliai izvertina erdvę ir laiką), reikia priimti ji sportuoti (Волков, 1981). Tik nesupraskite klaidingai, kad šiuo etapu nereikia įvertinti ir kitu ypatybiu lygio. Preliminarios atrankos pradžioje, taip pat po 1-o, 3-io ir 6-o mènesio pratybų, trukdžių i̇vertinimo siūloma nustatyti fizinio išsivystymo, jègos, staigiosios jègos, jègos ištvermès rodiklius ir jų gerèjimą (1 lent.) (Романов, Дегтерев, 1984).
Boksininkas turi būti stiprios, stabilios ir dinamiškos nervų sistemos, turèti gerai išlavintas valios savybes, iš kurių išskirtinès ryžtingumas, pasitikejjimas savimi, atkaklumas. Fizinè veikla, atliekama esant didelei nervinei ir emocinei apkrovai, reikalauja didelių valios pastangu (Волков, 1981), turi būti gerai išlavinti sportininko specialieji pojūčiai (nuotolio, laiko, smūgio jutimas, judesių laisvumas). Boksininkas visada turi būti susikaupęs, greitai ir tiksliai reaguoti i varžovo veiksmus, juos nuspèti, greitai mąstyti ir orientuotis ringe. Kai kurios ypatybès gali būti sil- 
2 lentelè. Jaunųjų boksininkų techninio ir taktinio, fizinio ir psichinio parengtumo kontroliniai normatyvai antruoju atrankos etapu (13-15 m.)

\begin{tabular}{|c|c|c|c|}
\hline Pavardè, vardas & \multicolumn{3}{|c|}{ İvertinimas } \\
\hline Rodikliai & Gerai (8) & L. gerai (9) & Puikiai (10) \\
\hline $\begin{array}{l}60 \text { m. bėgimas, s } \\
\text { (Романов, Дегтерев, 1984) }\end{array}$ & 9,2 & 9,0 & 8,8 \\
\hline $\begin{array}{l}500 \text { m krosas, s } \\
\text { (Задорожный, Хохлов, 2004) }\end{array}$ & 115 & 110 & 105 \\
\hline $\begin{array}{l}\text { Šuolis ị toli ịsibègejus, cm } \\
\text { (Гаськов, Кузьмин, 2008) }\end{array}$ & 360 & 380 & 390 \\
\hline $\begin{array}{l}\text { Teniso kamuoliuko metimas, m } \\
\text { (Задорожный, Хохлов, 2004) }\end{array}$ & 30 & 34 & 38 \\
\hline $\begin{array}{l}\text { Prisitraukimai, kartai } \\
\text { (Филин,1987) }\end{array}$ & 4 & 5 & 6 \\
\hline $\begin{array}{l}\text { Atsispaudimai, kartai } \\
\text { (Čepulènas ir kt., 2007) }\end{array}$ & 16 & 18 & 20 \\
\hline $\begin{array}{l}\text { Paprasta reakcija, ms } \\
\text { (Худадов, Фролов, 1970) }\end{array}$ & 205 & 198 & 196 \\
\hline $\begin{array}{l}\text { Sudètinga reakcija, ms } \\
\text { (Худадов, Фролов, 1970) }\end{array}$ & 260 & 245 & 240 \\
\hline $\begin{array}{l}\text { Rankos judesio dažnis ir greitis, s } \\
\text { (Skernevičius ir kt., 2004) }\end{array}$ & $12,6-12,0$ & $11,9-11,4$ & $<=11,3$ \\
\hline $\begin{array}{l}\text { Nuotolio jutimas specifinèmis sąlygomis (vertinta naudojant } \\
\text { Nikifirovo metodika) } \\
\text { (Худадов, Фролов, 1970) }\end{array}$ & $\begin{array}{l}\text { Paklaida ne didesnè } \\
\text { kaip } 7,2 \pm 0,3 \mathrm{~cm}\end{array}$ & 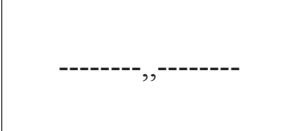 & \\
\hline Atsakyti i 3 teorinius klausimus (Романов, Дегтерев, 1984) & $\begin{array}{c}\text { Atsakius su } 2 \\
\text { nedidelèm klaidom }\end{array}$ & $\begin{array}{l}\text { Atsakius su nedidele } \\
\text { klaida }\end{array}$ & $\begin{array}{c}\text { Atsakius } \\
\text { nepriekaištingai }\end{array}$ \\
\hline $\begin{array}{l}\text { Mokèjimas atlikti tiesius, šoninius, apatinius smūgius i } \\
\text { galvą, korpusą ir gintis nuo јų (Романов, Дегтерев, 1984) }\end{array}$ & $\begin{array}{l}\text { Atlikus puikiai, tačiau } \\
\text { padarius nedidelius } \\
\text { aritmiškus nukrypimus }\end{array}$ & $\begin{array}{l}\text { Atlikus puikiai, tačiau } \\
\text { padarius nedidelius } \\
\text { nukrypimus }\end{array}$ & $\begin{array}{l}\text { Atlikus puikiai, } \\
\text { nepriekaištingai }\end{array}$ \\
\hline $\begin{array}{l}\text { Mokejjimas atlikti dvigubus tiesius šoninius, apatinius } \\
\text { smūgius i galvą, korpusą ir gintis nuo jų } \\
\text { (Романов, Дегтерев, 1984) }\end{array}$ & --------,,-------- & ,-------- & ,-------- \\
\hline $\begin{array}{l}\text { Mokejjimas atlikti ịvairias serijas iš } 3-4 \text { smūgiu i galvą, } \\
\text { korpusą ir gintis nuo jų } \\
\text { (Романов, Дегтерев, 1984) }\end{array}$ & & & \\
\hline $\begin{array}{l}\text { Mokèjimas atlikti judèjimo, smūgių ir gynybos veiksmus iš } \\
\text { tolimojo ir vidutinio nuotolio (Романов, Дегтерев, 1984) }\end{array}$ & ---------,,-------- & -,-,------ & \\
\hline $\begin{array}{l}\text { Mokèjimas atlikti atakos ir kontratakos veiksmus (Романов, } \\
\text { Дегтерев, 1984) }\end{array}$ & --------,,-------- & ---- & -- \\
\hline
\end{tabular}

Pastaba. --------,------- — naudojamos tokios pat vertinimo sąlygos kaip ir minètos anksčiau. Рarengta pagal Худадов, Фролов, 1970; Гужаловский и др., 1971; Романов, Дегтерев, 1984; Задорожный, Хохлов, 2004; Čepulènas ir kt., 2007 rekomendacijas.

pnesnès, bet tuomet būtina jas kompensuoti kitomis (Худадов, Фролов, 1970; Мелихова, 1990; Худадов, 1998; Филимонов, 2006).

Daugumos silpnų boksininkų šios ypatybės yra prastai išugdytos, ir niekas jų nekompensuoja. Dèl to jie praleidžia daug smūgių, dažnai būna traumuojami ir pralošinèja kovas (Худадов, Фролов, 1970; Гужаловский, 1978).

Galima garantuoti, kad naujokai, kurių minètos psichinès funkcijos yra prastos, net ir turèdami gerus fizinius duomenis negalètų kultivuoti bokso, išskyrus tuos atvejus, kai po tam tikro laiko (2-3 mènesiu) vienas funkcijas pradeda kompensuoti kitomis. Ivertinęs testų rezultatus, tokiems naujokams treneris turètų pasiūlyti kitą sporto šaką (Белашев, 2000; Худадов, Васильев, 2001).

Vaikai yra labilesnès nervų sistemos, ir tai jiems leidžia ne tik greičiau reaguoti i ivvairius dirgiklius, bet greičiau išmokti ịvairių dinaminių igūdžių. Kai kurios psichinès jaunų boksininkų 
3 lentelè. Vaikų fizinio pasirengimo rodiklių rezultatai ir jų pokyčiai procentais

\begin{tabular}{|c|c|c|c|c|c|c|c|c|c|c|c|c|c|}
\hline $\begin{array}{c}\text { Pavarde், } \\
\text { vardas, }\end{array}$ & \multicolumn{13}{|c|}{ Rezultatai } \\
\hline \multirow[t]{2}{*}{ Rodikliai } & \multirow[t]{2}{*}{ Pradiniai } & \multicolumn{2}{|c|}{ Po 1 mèn. } & \multicolumn{2}{|c|}{ Po 3 mèn. } & \multicolumn{2}{|c|}{ Po 6 mèn. } & \multicolumn{2}{|c|}{ Po 1 m. } & \multicolumn{2}{|c|}{ Po 1,5 m. } & \multicolumn{2}{|c|}{ Po 2 m. } \\
\hline & & $\begin{array}{c}\text { Rezul- } \\
\text { tatas }\end{array}$ & $\begin{array}{c}\text { Pokytis } \\
\%\end{array}$ & $\begin{array}{c}\text { Rezul- } \\
\text { tatas }\end{array}$ & $\begin{array}{c}\text { Pokytis } \\
\% \\
\end{array}$ & $\begin{array}{c}\text { Rezul- } \\
\text { tatas }\end{array}$ & $\begin{array}{c}\text { Pokytis } \\
\% \\
\end{array}$ & $\begin{array}{c}\text { Rezulta- } \\
\text { tas }\end{array}$ & $\begin{array}{c}\text { Pokytis } \\
\%\end{array}$ & $\begin{array}{c}\text { Rezulta- } \\
\text { tas }\end{array}$ & \begin{tabular}{|c|} 
Pokytis \\
$\%$ \\
\end{tabular} & $\begin{array}{c}\text { Rezulta- } \\
\text { tas }\end{array}$ & $\begin{array}{c}\text { Pokytis } \\
\%\end{array}$ \\
\hline $\begin{array}{l}60 \mathrm{~m} \\
\text { bėgimas }\end{array}$ & & & & & & & & $9,5-9,7$ & & $9,4-9,6$ & 2,12 & $9,3-9,5$ & 1,07 \\
\hline
\end{tabular}

funkcijos beveik nesiskiria nuo patyrusiujų. $\mathrm{Pa}$ vyzdžiui, pradedančiujų boksininkų paprastas reagavimas kur kas geresnis negu patyrusių. Taip pat nèra didelių reakcijos skirtumų, kai atliekama nedaug užduočių, bet skiriasi varžovo veiksmu prognozavimas, sudètingesnès informacijos įvertinimas, greito ir tikslaus sprendimo priemimas (Мартынов, 2002 ).

Atliekant pirminę vaikų atranką i pradinio rengimo bokso grupes, siūloma nustatyti mažai kompensuojamas psichines sportininko funkcijas ir vestibulini jautrumą. Kadangi naujesnių moksliniu tyrimų šia tema nèra, rèmėmès N. A. Hudadovu ir O. P. Frolovu (Худадов, Фролов, 1970), kurie per pirmines atrankas siūlo įvertinti informacijos prièmimo ir apdorojimo greiti, demesio paskirstymą ir intensyvuma, nuotolio jutima, vestibulini jautruma (1 lent.). Preliminarios atrankos pranašumas prieš kitas yra tas, kad psichinès funkcijos testuojamos nespecifinèmis sąlygomis. Naujokai neturi specialių gebejjimų testų užduotims atlikti specifinėmis sąlygomis (jie neturi gebejimų, kuriais remiantis modeliuojama boksininko veikla) (Худадов, Фролов, 1970).

Be jau minètu psichiniu funkcijų įvertinimo, mokslininkai (Худадов, Фролов, 1970; Волков, 1981; Романов, Дегтерев, 1984; Задорожный, Хохлов, 2004) siūlo atrinkti vaikus ì pirmų metų pradinio rengimo grupes papildomai ivertinant pasitikejjimą savimi, greitumo, jègos, staigiosios jègos, jëgos ištvermès ir paprasčiausių specialiuju koordinacinių gebejjimų išmokimo lygi. Visi šiu ypatybiu ivertinimo testai ir normatyvai pateikti 1 lentelèje.

Antrojo atrankos etapo tikslas yra jaunuju boksininkų meistriškumo tobulèjimo prognozavimas. Šiuo etapu dauguma rekomenduojamu testų modeliuoja specifines boksininkų veiklos sąlygas ringe.

Antruoju atrankos etapu mokslininkai (Xyдадов, Фролов, 1970; Мартынов, 2002) siūlo ivertinti: paprastą reakciją, sudètingą reakciją, rankos judesių dažnį ir greiti; nuotolio jutimą spe- cifinėmis sąlygomis. Kiti mokslininkai (Волков, 1981; Романов, Дегтерев, 1984; Худадов, Васильев, 2001) dar siūlo îvertinti greitumo, jègos, staigiosios jègos, jëgos ištvermès, ištvermès, sudėtingesnių specialiuju koordinacinių gebejjimu išmokimo lygi ir teorines žinias. Visi testai ir normatyvai šioms ypatybėms iqvertinti pateikti 2 lentelèje.

Pirmoje lentelèje palikti tušti langeliai yra tam, kad treneris ar mokytojas surašytų testų rezultatus (pradinius ir po atitinkamo laikotarpio), iš kuriu kaitos treneris turès informacijos apie treniruočiu poveiki sportininko rezultatui. Treneris matys pradinius sportininko rezultatus ir kiek jie pakito per tam tikrą laika. Kaip teigia A. Zutkis (1981), atrenkant perspektyvūs yra ne tie vaikai, kuriu geri pradiniai rezultatai, o tie, kurių dideli pagrindiniu fizinių ypatybiu gerejimo tempai per pirmuosius pusantrų ar dvejus pratybų metus. Iš tirtų rodikliu rezultatu kaitos bus galima spręsti apie vaiko tinkamumą bokso sporto šakai. Taip pat šalia testų rezultatų galima būtų susiskaičiuoti ir tirtų rodiklių rezultatų pokyčius procentais. Manome, kad tuomet rezultatú pokyčiai būtų dar akivaizdesni. Pavyzdžiui, kaip 3 lentelejje.

Optimalus amžius bokso treniruočių pradžioje ir tinkamas geriausiems sportiniams rezultatams pasiekti, sportinio stažo trukmè. Šiuo metu pagal sporto mokyklų programas vaikai i pradinio rengimo bokso grupes priimami nuo 12-14 m. S. A. Polijevskis ir kt. (Палиевский и др., 2002) nustatè, kad bokso treniruotes pradeda lankyti vis jaunesni vaikai. 1978 metų duomenimis, vidutinis pradinès bokso specializacijos laikas $-15,7$ m. (Zutkis, 1981). 1983 m. P. Siris ir 1990 m. T. Melichova siūlè pradèti dar anksčiau nuo $10-11 \mathrm{~m}$. J. Winfried (2001) teigia, kad kuo jaunesni vaikai, tuo lengviau tobulinamas ju psichologinis ir fizinis rengimas. Ivairi ir nedidelè fizinè apkrova šiuo amžiaus tarpsniu (10-13 m.) ir santykiškai didelè specialioji fizinè apkrova nuo $16 \mathrm{~m}$. leidžia pasiekti puikių sportinių rezultatų sportininkui subrendus (Мелихова, 1990). Visgi 
treneriai turi atsiminti, kad amžius, nuo kada patariama lankyti pratybas, priklauso nuo sporto šakos. Per ankstyvas treniruotės vyksmo specializavimas trukdo bendram fiziniam, moraliniam vaiko valios vystymuisi, neleidžia atskleisti talentingu ir perspektyvių vaikų, padidina traumų galimybes. Būtent dèl to daug vaikų nustoja treniruotis ne tik pradinio rengimo, bet ir meistriškumo ugdymo ir tobulinimosi etapais. Todèl vienas iš svarbiausiu pradinės atrankos ypatumų bokso srityje yra optimalus vaiko amžiaus parinkimas pratybų pradžiai (Полиевский и др., 2002).

Laikantis psichomotorinių vystymosi dèsningumų, metodologiniu principu ir saugumo taisyklių, oficialią amžiaus ribą pradėti lankyti bokso pratybas galima sumažinti iki 9-10 m. (Мартынов, 2002; Полиевский и др., 2002).

Sportinès treniruotès vyksme labai svarbus yra amžius, kuriam esant sportininkai pasiekia stabiliu ir puikių rezultatú. Remdamasis šiuo dèsningu$\mathrm{mu}$, treneris daugiametę sporto treniruotę gali suplanuoti taip, kad geriausių pasiekimų amžius sutaptų su tuo, kuriam esant pasiekiama pastoviu rezultatų. Šis amžiaus tarpsnis sutampa su visišku organizmo potenciniu galimybiu išsivystymu. Tik tokio amžiaus sportininkas gali ne tik pasiekti puikiu rezultatu, bet ir sportuoti ilgus metus (Zutkis, 1981).

V. P. Filinas (Филин, 1987) nustatè, kad pirmujų didelių laimèjimų boksininkai pasiekia būdami 18-20 metų, optimaliu - 21-24 m., o geba išlaikyti puikius - iki $27 \mathrm{~m}$. Bet, kaip rodo Lietuvos boksininkų rezultatų statistika, jų rezultatai puikūs net iki 30 metų. Pavyzdžiui, D. Pozdniakas olimpiniu čemionu tapo būdamas net 29 m., R. Tamulis trečią kartą Europos čempionu tapo 28-erių, V. Karpačiauskas Europos čempionu - 26-eriu, o pasaulio prizininku 28-eriu.

Sportinio stažo trukmé. Laikotarpis, per kuri galima pasiekti geriausių sportinių rezultatų, yra labai svarbus tuo, kad nuo jo priklauso sportinio meistriškumo valdymo procesas, atskiros jos dalys (daugiametis ir einamasis planavimas, treniruotès priemoniu ir metodų parinkimas, krūvio dydžiai ir pan.) (Zutkis, 1981). Dar nèra nustatyta ryšio tarp ankstyvos bokso specializacijos ir greito rezultatu gerejjimo. Ankstyva sportinè specializacija dažnai ne sutrumpina, o, priešingai, pailgina rezultatu pažangą. Treneriams reikètu atkreipti démesi i tai, kad ankstyvos specializacijos metu nukenčia tų vaiku bazinis bendrasis fizinis parengtumas, jiems greitai atsibosta pasirinkta sporto šaka, atsiranda noras išbandyti save kultivuojant kitas sporto šakas. Kad ir kaip treneris norètu greitų rezultatų, jis neturi teisès treniruotès vyksmą forsuoti, t. y. stengtis kuo greičiau pasiekti puikiu sportiniu rezultatu (Волков, 1981; Мелихова, 1990). Dèl to labiausiai kenčia gabūs ir talentingi vaikai. Sportineje praktikoje yra daug pavyzdžių, kada labai gabūs vaikai jau paauglysteje išsisemia ir meta bokso treniruotes. Tai rodo, kad treneriai nepakankamai gerai išmano vaiku amžiaus ypatumus, individualias vaiku ypatybes, sportinio rengimo dèsningumus. Prof. V. M. Volkovo teigimu, vidutinè boksininko sportinio stažo trukmè, per kurią galima pasiekti geriausių sportiniu rezultatų, yra apie 10,7 m. (Zutkis, 1981).

\section{IŠVADOS}

Gabumai yra genetiškai determinuoti ir pasireiškia tik konkrečioje sportinejje veikloje, o už šios veiklos jie gali iš viso neegzistuoti.

Boksininko sportinio meistriškumo lygis priklauso ne tik nuo fiziniu, funkciniu, bet ir nuo psichiniu ypatybiu.

Bokso pratybas pradèti lankyti galima ne anksčiau kaip nuo 9-10 m.

Svarbiausias preliminarios atrankos tikslas yra ivertinti trukdžių (trukdys - tai tokios ypatybès, kurios neleis vaikui siekti puikių sportiniu rezultatu) lygi: lètas informacijos prièmimas ir apdorojimas, nepakankamas demesio paskirstymas ir jo intensyvumas, prastas erdvès ir laiko vertinimo tikslumas.

Pirminiu atrankos etapu reikia nustatyti boksininku vestibulinę funkciją ir jos kaitą, pasitikejimą savimi, greitumą, jẻgą, staigiają jègą, ištvermę, gebejimą parodyti tiesius smūgius ir gynybą nuo jų.

Antruoju boksininku atrankos etapu reikia nustatyti sportininku greitumą, jègą, staigiają jègą, ištvermę, technikos veiksmų lygị ir kaitą, nuotolio jutimą specifinemis sąlygomis, paprastą ir sudètingą reakciją, taip pat jie turi atsakyti i 3 teorinius klausimus. 


\section{LITERATŪRA}

Čepulènas, A., Subačius, V., Bružas, V., Mockus, P. (2007). The alteration of young boxers' athletic and special physical fitness during the first year of their physical training. Ugdymas. Kūno kultūra. Sportas, 4 (67), 5-11).

Michel, G., Novak, F. (1983). Stichwort "Begabung". In Kleines psychologisches Wörterbuch. Freiburg (1975), 8. Auflage. P. 43- 44.

Platonas. (2000). Valstybè. 2-asis pataisytas leidimas. Vilnius: Pradai.

Radžiukynas, D. (2005). Jaunuju lengvaatlečiu atranka ir rengimas: mokymo priemonè kūno kultūros specialybès studentams. Vilnius.

Rušas, R., Bagočiūnas, S. (1999). Sporto treniruotės poveikis vestibulinėms somatinėms reakcijoms. Ugdymas. Küno kultūra. Sportas, 2 (31), 53-56.

Skernevičius, J., Raslanas, A., Dadelienè, R. (2004). Sporto mokslo tyrimu metodologija. Vilnius: Lietuvos sporto informacijos centras.

Thiess, G. (1989). Die auswahl sportlicher talente in der DDR. Versuch eines historischen überblicks. Leistungssport, 19 (5), 11-14.

Winfried, J. (2001). Das sportliche talent: Talenterkennung-Talentförderung - Talentperspektiven. Aufl.-Aachen: Meyer und Meyer.

Zutkis, A. (1981). Jauniu sportinès treniruotès sistemos pagrindai: metodinès rekomendacijos. Vilnius. P. $54-63$.

Аристотель. (1975). Метафизика: соч. Т. 2. Москва: Мысль. С. 239-240.

Белашев, А. И. (2000). Методика спортивного отбора юных боксёров: gис. на соиск. учён. степени канд. пед. наук. Волгоград. Prieiga internetu: РГБ ОД, 61:01$13 / 1455-4$

Волков, В. М. (1981). Спортивные способности детей. Смоленский государственный институт физической культуры.

Гаськов, А. В. Кузьмин, В. А. (2008). Модельные характеристики соревновательной деятельности боксёров-юношей. Физическое воспитание студентов творческих специальностей, 2, 3-11.

Задорожный, Л., Хохлов, Г. (2004). Исследования уровня общей физической работоспособности у боксёров различных весовых категорий, возраста и квалификации. Физическое воспитание студентов творческих специиальностей ХГАДИ (ХХПИ), 5, 29-34.

Запорожанов, В. А. (отв. редактор). (1990). Отбор, контроль и прогнозирование в спортивной тренировке: сборник научых трудов. Киев: КГИФК.
Зациорский, В. М., Булгаков, Н. Ж. (1980). Теоретические и метрологические основы отбора в спорте: учебное пособие. Москва.

Кличко, В. (1999). Бокс: теория и методика спортивного отбора. Киев: Нора принт.

Мартынов, М. В. (2002). Отбор и подготовка юных боксёров в условиях общеобразовательной школьг с учётом показателей психомоторики: gис. на соиск. учён. степени канд. пед. наук. Москва.

Мелихова, Т. М. (1990). Отбор детей для занятий конькобежным спортом на основе комплекса критериев: учебное пособие. Омск, Челябинск. С. 3-8.

Платонов, В. Н., Запорожанов, В. А. (1991). Отбор и прогнозирование перспективности спортсменов на начальных этапах многолетней подготовки. Управление тренировочным проиессом на основе учёта индивидуальных особенностей юных спортсменов: тез. докл. ХІІІ Всесоюз. науч.-практ. конф. Харьков, 28-31 мая. (сс. 98-99). Москва.

Платонов, К. К. (1972). Проблемы способностей. Москва: Наука.

Полиевский, С. А., Подливаев, Б. А., Худадов, Н. А., Киселев, В. А., Мартынов, М. В. (2002). Возрастная граница начала занятий боксом. Физическая культура: воспитание, образование, тренировка. Детский тренер: Журнал в журнале, 4, 2-6.

Романов, В. М., Дегтярев, И. П. (1984). Бокс. Москва: Физкультура и спорт.

Таймазов, В. А., Бакулев, С. Е. (2005). Прогнозирование успешности соревновательной деятельности спортсменов с учётом генетических основ тренируемости Учёнье записки университета имени П.Ф. Лесгафта, $18,81-90$.

Филимонов, В. И. (2006). Теория и методика бокса: монография. Москва: Инсан.

Филин, В. П. (1987). Теория и методика юноческого спорта. Москва: Физкультура и спорт.

Худадов, Н. А., Васильев, Г. Ф. (2001). Прогнозирование олимпийского результата в боксе: сборник научных трудов ВНИИФК. Москва. С. 266-268.

Худадов, Н. А., Фролов, О. П. (1970). Bопросы психологического отбора боксёров: методическое письмо. Москва.

Шварц, В. Б. (1978). К проблеме врождённого и приобретённого в развитии двигательных способностей. В сборнике: Проблемы генетической психофизиологии человека. Москва. 


\title{
PROBLEM OF SELECTION, MAJOR RECOMMENDATIONS AND MODEL CHARACTERISTICS IN THE PROCESS OF SELECTING YOUNG BOXERS FOR INITIAL TRAINING GROUPS
}

\author{
Vidas Bružas, Vitalijus Subačius \\ Lithuanian Academy of Physical Eduication, Kaunas, Lithuania
}

\begin{abstract}
The analysis of literature as well as our practical experience suggest that boxing coaches are not provided with sufficient amount of information and rarely apply the scientifically grounded selection and prediction criteria which would enable them to evaluate children's skills and possibilities more precisely.

It is possible to state that presently the initial selection for boxing training groups does not exist. The main task of coaches and sports schools is the formation of groups. As a result of the absence of selection criteria or the inability to successfully apply them, most children abandon sports during the initial training stage (Мелихова, 1990; Winfried, 2001) what has a negative effect on the preparation of highly skilled boxers (Белашев, 2000; Полиевский и др., 2002; Гаськов, Кузьмин, 2008).

The goal of the present research was to evaluate the problem of skills and selection through literature analysis, to systemize the obtained data and to provide major recommendations and model characteristics which are crucial in the process of selecting young and promising boxers for initial training groups.

Major conclusions: 1. Skills are genetically determined and are manifested only through a particular type of physical activities beyond which they may not even exist; 2 . Boxer's excellence and skills depend not only on the physical and functional characteristics, but also on the mental condition of the sportsperson. 3 . The youngest age to start learning boxing is $9-10$ years; 4 . The main aim of the preliminary selection is to evaluate the level of the limiting characteristics (limiting characteristics are such characteristics which would obstruct the child's effort to achieve excellent results in sport): slow reception and generation of information, lack of attention or inability to distribute it adequately, poor ability to precisely evaluate the space-time characteristics; 5 . During the initial selection of boxers, in addition to the limiting characteristics, it is also important to evaluate the vestibular function and its dynamics, self-confidence, speed, strength, impulse strength, and endurance, potential boxers should be able to show straight knocks and basic defense; 6. During the secondary selection, it is important to evaluate the sportspersons' speed, strength, impulse strength, endurance, the level of technical actions and dynamics, the perception of distance under specific conditions, simple and complex reaction; they also have to answer 3 theoretical questions.
\end{abstract}

Keywords: boxing, problem of selection and skills, recommendations, model characteristics, primary training groups.

Gauta 2010 m. sausio 27 d.

Received on January 27,2010

Priimta 2010 m. gegužès $31 \mathrm{~d}$

Accepted on May 31, 2010

Vidas Bružas

Lietuvos kūno kultūros akademija

(Lithuanian Academy of Physical Education)

Sporto g. 6, LT-44221 Kaunas

Lietuva (Lithuania)

Tel +370 37302664

E-mailv.bruzas@1kka.1t. 